\title{
Propagule pressure drives establishment of introduced freshwater fish: quantitative evidence from an irrigation network
}

\author{
Darragh J. Woodford, ${ }^{1,2,4}$ Cang Hui, ${ }^{3}$ David M. Richardson, ${ }^{3}$ and Olaf L. F. Weyl ${ }^{1,2}$ \\ ${ }^{1}$ South African Institute for Aquatic Biodiversity, Grahamstown, South Africa \\ ${ }^{2}$ Centre for Invasion Biology, South African Institute for Aquatic Biodiversity, Grahamstown, South Africa \\ ${ }^{3}$ Centre for Invasion Biology, Department of Botany and Zoology, Stellenbosch University, South Africa
}

\begin{abstract}
Propagule pressure is recognized as a fundamental driver of freshwater fish invasions, though few studies have quantified its role. Natural experiments can be used to quantify the role of this factor relative to others in driving establishment success. An irrigation network in South Africa takes water from an inter-basin water transfer (IBWT) scheme to supply multiple small irrigation ponds. We compared fish community composition upstream, within, and downstream of the irrigation network, to show that this system is a unidirectional dispersal network with a single immigration source. We then assessed the effect of propagule pressure and biological adaptation on the colonization success of nine fish species across 30 recipient ponds of varying age. Establishing species received significantly more propagules at the source than did incidental species, while rates of establishment across the ponds displayed a saturation response to propagule pressure. This shows that propagule pressure is a significant driver of establishment overall. Those species that did not establish were either extremely rare at the immigration source or lacked the reproductive adaptations to breed in the ponds. The ability of all nine species to arrive at some of the ponds illustrates how longterm continuous propagule pressure from IBWT infrastructure enables range expansion of fishes. The quantitative link between propagule pressure and success and rate of population establishment confirms the driving role of this factor in fish invasion ecology.
\end{abstract}

Key words: biological invasions; Cyprinus carpio; Gambusia affinis; inter-basin water transfer; invasion corridor; natural experiments; Oreochromis mossambicus; reproductive guild.

\section{INTRODUCTION}

Many factors influence the establishment of introduced species. Understanding the role of different factors and their interactions is a fundamental challenge to ecologists, biogeographers, and conservation managers (Hayes and Barry 2008). Insights have emerged from inferring which processes operate and how they interact by examining patterns of success and failure over long periods and across environments (Ruesink 2005). Experimental work has shed further light on this complex problem, for instance, by demonstrating the importance of initial propagule pressure (Memmott et al. 2005, Von Holle and Simberloff 2005) and early biotic resistance (Humphrey and Schupp 2004) in determining establishment success. Natural experiments, where natural patterns in species establishment can be assessed following an experimental design, provide opportunities to gain a deeper understanding of the processes that drive invasion success (Holway 1998).

Freshwater fish invasions are becoming more widespread and their impacts more damaging worldwide, especially in the case of introduced predatory fish (Cox

Manuscript received 24 July 2012; revised 21 March 2013; accepted 17 May 2013. Corresponding Editor: A. K. Ward.

${ }^{4}$ E-mail: darraghwoodford@hotmail.com and Lima 2006). Managing these invasions is challenging because many anthropogenic vectors are difficult to control (Richardson et al. 2003). A theoretical framework for understanding fish invasions (Moyle and Light 1996) conceptualized the invasion process in terms of three fundamental stages: arrival, establishment and integration. The first two of these stages involve environmental and demographic barriers that must be overcome (Moyle and Light 1996, Moyle and Marchetti 2006). The integration stage involves population-level success in overcoming all these environmental and demographic "filters," and is the stage where the recipient ecosystem may become altered (i.e., invasion; Moyle and Light 1996, Moyle and Marchetti 2006, see also Blackburn et al. 2011). Success in reaching the initial arrival stage depends on propagule pressure (Marchetti et al. 2004), which is defined as the size (i.e., number of propagules) and frequency of introductions (Williamson and Fitter 1996). Successful establishment depends on the life-history strategies of species (Olden and Poff 2006), adaptation to environmental variability (Fausch et al. 2001), and on-going interactions between these factors and propagule pressure (Marchetti et al. 2004, Ruesink 2005). The driving role of propagule pressure in determining introduced species establishment success has been demonstrated for many groups of introduced organisms (Simberloff 2009), and 


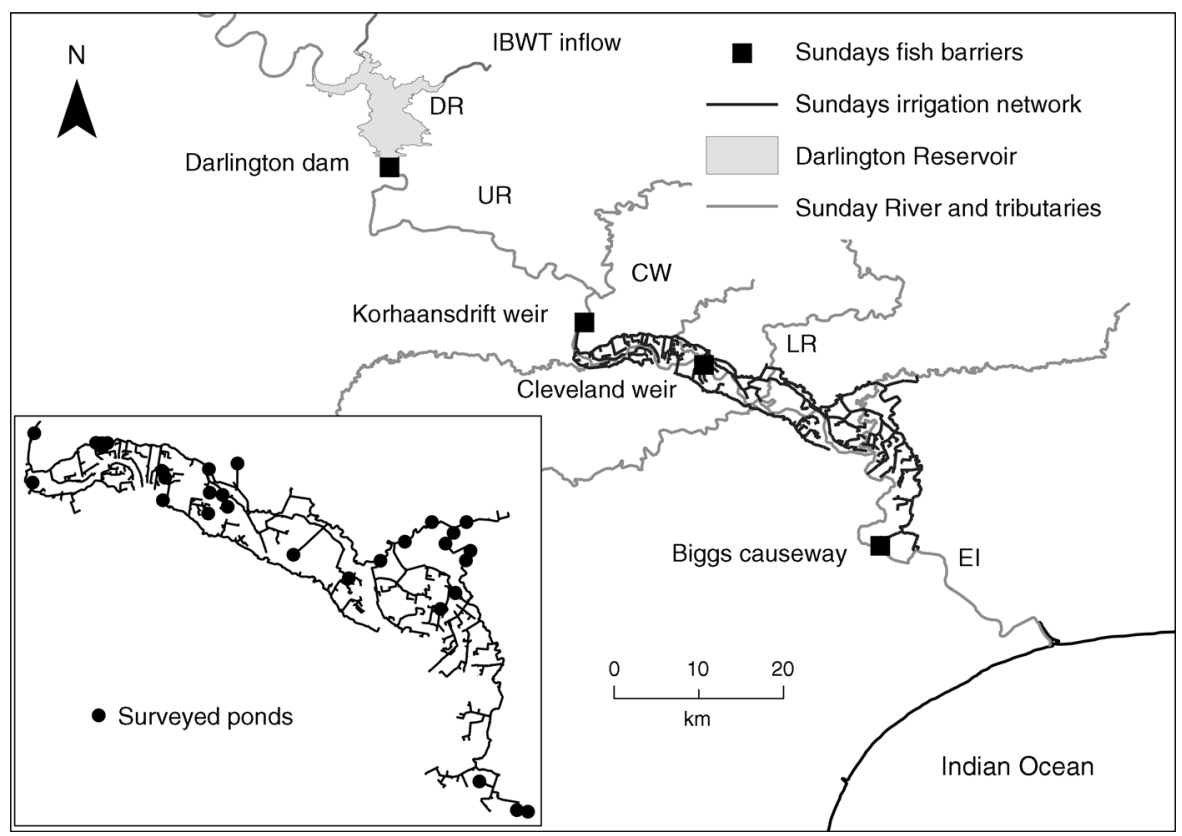

FIg. 1. The Sundays River, South Africa, and its associated tributaries. Water from the Orange-Vaal catchment enters the system at Darlington Dam, after which it is circulated through the Sundays irrigation network before spilling back into the Sundays River. Major barriers to upstream fish movement are labeled with squares on the main stream. The inset shows localities of 30 sampled irrigation ponds across the network. Faunal zones along the Sundays River (excluding the irrigation network) are labeled as follows: within Darlington reservoir (DR); river upstream of the off-take canal at Korhaansdrift (UR); river upstream of Cleveland weir in the middle reaches $(\mathrm{CW})$; lower river between Cleveland weir and the Biggs causeway (LR); and below Biggs causeway in the estuarine-influenced zone (EI). IBWT stands for inter-basin water transfer.

has been suggested as a null model for explaining most invasions (Colautti et al. 2006, Lockwood et al. 2009). The lack of quantitative assessments of propagule pressure is a significant knowledge gap in understanding freshwater fish invasions (Copp et al. 2007, GarcíaBerthou 2007).

Irrigation infrastructure, in the form of canals, tunnels, and water transfer schemes, is an important component of the pathways whereby fish distributions are influenced by human activities. Such infrastructure lends itself to quantitative assessment, due to the physically constrained nature of the pathway and the ability to link introduction events to water flow. This provides exciting opportunities to improve our understanding of how different factors mediate invasions. The largest and most significant infrastructures of this type are inter-basin water transfer (IBWT) schemes. In the pathway framework of Wilson et al. (2009), IBWTs are invasion corridors that create multiple, continuous, dispersal opportunities between regions. They connect previously isolated catchments, enabling the passive dispersal of many aquatic organisms, with potentially momentous ecological consequences (Meador 1992, Rahel 2007).

South Africa is a global hotspot for alien fish invasion, partly due to the spread of organisms through IBWT schemes (Richardson et al. 2003, 2011, van Rensburg et al. 2011). The Orange-Fish-Sundays IBWT scheme was completed in 1978 and has resulted in the passive introduction of five species of fish into the Sundays River basin, Eastern Cape province. Most introduced species entered this basin at the outflow of the IBWT (at Darlington reservoir). However, their spread throughout the catchment has been mediated to some degree by a complex network of smaller irrigation canals that distribute water to hundreds of small irrigation ponds on farms (Fig. 1). The irrigation scheme is a highly dynamic artificial aquatic landscape, in which fish introductions are on-going as new ponds are built to supply agricultural expansion. The system represents a natural experiment, where establishment rates of introduced fish can be assessed by comparing populations in ponds with a range of filling histories, and where propagule pressure can be estimated as a continuous variable over time, using immigrant densities at the source of the network.

We assessed whether the Sundays irrigation network could be used to quantitatively link establishment success to propagule pressure by confirming the oneway dispersal characteristics of the network, with the off-take canal as a single immigration source and the ponds being multiple immigration sinks. To achieve this, fish communities across the irrigation network were compared to previously collected data on the main stream of the Sundays River. We hypothesized that all fish species present in the river upstream of the off-take 
should be present in the ponds as a result of network connectivity. We further hypothesized that all other connections to the Sundays River were unidirectional pathways, with fish only able to disperse downstream, but unable to enter the network upstream from these lower connection points. Finally, we posited that those fish species entering the irrigation network in large numbers would be more likely to colonize the irrigation ponds rapidly and have self-sustaining populations in both young and old ponds, whereas species recorded entering the network infrequently would establish slowly or not at all. By linking the magnitude of propagule pressure to the success and rate of establishment in the ponds, our aim was to assess whether one could quantify the role of propagule pressure in allowing fishes to achieve the arrival and establishment stages of invasion.

\section{Methods}

\section{The study system}

The IBWT enters the Sundays System at Darlington Reservoir (Fig. 1). Water released from the dam flows 50 $\mathrm{km}$ downstream to Korhaansdrift weir where most of the flow is diverted into the irrigation network. The main Sundays River continues downstream across major dispersal barriers at Cleveland weir and Biggs causeway, the latter marking the estuarine interface. We divided the main stream into five river reaches: Darlington reservoir at the top; the upper reaches of the river upstream of the off-take canal at Korhaansdrift weir; the river upstream of Cleveland weir in the middle reaches; lower river between Cleveland weir and the Biggs causeway; and the estuarine influenced zone below the Biggs causeway (Fig. 1). The off-take canal at Korhaansdrift weir directs water away from the river and into the irrigation network. Within the network, water flows via gravity down several major and minor concrete canals, eventually feeding about 390 small offchannel irrigation ponds. There are also several "reject" canals that empty the water and fish from the main canals back into the Sundays River, the last being downstream of Biggs causeway. Each pond has a gravity-fed inflow, where water purchased by the landowner is introduced from the canal system (see Appendix A for illustrative photograph). Water is siphoned out of the pond through pipes filtered to prevent the passage of fish. The ponds are therefore dispersal sinks for all introduced fish. Irrigation ponds receive an annual quota of water based on the area irrigated.

\section{Darlington reservoir and Sundays main stream surveys}

Fish distribution within the system was determined from surveys conducted between September 2007 and December 2010. Different sampling methods and equipment were used to sample the full range of habitats in the river, reservoirs, and weirs (see Appendix B). Because each sampling method has inherent species and size selectivity, catch rate and species composition data could not be compared directly between sites or gears. As a result, all catches from all sampling gears were grouped and only the presence/absence data were used to assess fish species distributions in the five river reaches.

\section{Introduction source surveys}

To establish the species composition and introduction rates entering the irrigation network, we deployed fyke and drift nets near the source of the main canal $200 \mathrm{~m}$ downstream of the off-take weir at Korhaansdrift, at the northernmost point of the canal network (Fig. 1). Sampling took place over six days in January and three days each in February, April, June, August, September, and November 2012. These sampling dates captured seasonal variation in fish movement, with the extended January sample targeting the time of year when maximum larval drift in most species was expected. Drift nets (WP2 or bongo nets with mouth diameter of $60 \mathrm{~cm}$ and mesh size $0.5 \mathrm{~mm}$ ) were suspended in the water column below a bridge. Sampling lasted two hours and was conducted morning, midday, early evening, and at night, to capture diel fluctuations in fish drift. Fyke nets were also deployed below bridges in the first $2 \mathrm{~km}$ of the main canal. Each fyke net had upstream and downstream facing traps with a $20 \mathrm{~mm}$ mesh size and a mouth area of $0.5 \mathrm{~m}^{2}$. In determining the number of fish propagules entering the network, we only assessed fish captured in the downstream trap of each fyke, as it was considered to be filtering water flowing downstream in a similar manner to the drift nets.

\section{Irrigation pond surveys}

Surveys of 30 irrigation ponds (Fig. 1) were conducted over two periods; a winter survey on 18 ponds in July 2011 and a summer survey on a further 12 ponds in January 2012. Selected ponds represented a range of ages from a number of hours since filling to 30 years of continuous inundation, and had no history of stocking by landowners. Site selection also ensured a range of both new and old ponds located at varying distances along the irrigation network from the source at Korhaansdrift. The location of ponds along the irrigation network was determined using a GIS model of the network provided by the Lower Sundays River Water Users Association (LSRWUA; Sunland, South Africa). We determined distance from the immigration source at Korhaansdrift to each surveyed pond using the Closest Facility tool in the Network Analyst toolkit in ArcGIS 10 (ESRI 2011). Pond area was measured on the ground and confirmed using georeferenced aerial photographs where possible (pond size ranged from $1089 \mathrm{~m}^{2}$ to $18900 \mathrm{~m}^{2}$ ). Mean depth was measured along a transect through the center of the pond. We collected physicochemical measurements using a YSI multi-probe sonde (YSI, Yellow Springs, Ohio, USA). Maximum and minimum pond temperatures were captured by a submerged temperature logger that recorded two-hourly 
temperatures for 12 months in a representative pond. Information on the age of each pond was provided by the landowners and the LSRWUA.

Fish were collected using a $30 \times 2 \mathrm{~m}$ seine with $12-\mathrm{mm}$ mesh wings and an 8-mm mesh codend. We used between two and five seine samples per dam, depending on the surface area. For each sample, the net was deployed in a semicircle near the center of the pond by an inflatable boat and retrieved into a corner or the center of a dam wall. The sampling effort for each sample was calculated as the area covered by the seine pull, estimated as the semi-circular area within the net plus the area between the net and the shore at the beginning of retrieval. All fish retrieved were identified and the first 100 of each species were measured to the nearest millimeter.

\section{Characterizing invasion pathways into the ponds}

To confirm whether Korhaansdrift weir could be considered as the only source of immigration into the ponds, we compiled an assembly list based on species presence at each sampled region of the Sundays River, Darlington reservoir, the Korhaansdrift intake, and the ponds themselves. We compared the similarity of the fish communities across these sites to determine whether known and assumed upstream barriers to fish movement were characterized by dissimilarities in the fish assemblages. We employed Jaccard's coefficient of similarity to compare the difference between fish communities based on the presence/absence of shared species. The Jaccard coefficient ranges from 0 (no overlap) to 1 (completely similar). To test whether communities differed significantly in composition, we ran 1000 independent composition permutations based on the species-by-site matrix, and generated the Jaccard coefficients for 21000 paired assemblages. The one-tailed 5\% lower critical value $\left(d_{1}\right)$ and upper critical value $\left(d_{2}\right)$ were then determined from the 21000 Jaccard coefficients of the permutation test. Fish assemblages from paired sites with a Jaccard coefficient less than the lower critical value were considered significantly similar to each other $(P<0.05)$, while assemblages with a Jaccard coefficient greater than the upper critical value were considered significantly different from each other $(P<0.05)$.

\section{Assessing propagule pressure and establishment rates}

Propagule pressure for each species entering the irrigation network at the off-take was determined by estimating the mean number of fish entering the canal network per cubic meter of water filtered by the drift and fyke nets. Propagule pressure for each species entering each individual pond was estimated by multiplying the annual assigned quota of inflow $\left(\mathrm{m}^{3}\right)$ by the age of the pond and the mean density of fish recorded at the offtake. We assumed most farmers would utilize their full irrigation quota each year. For ponds less than one year old, the absolute volume of water purchased prior to the survey was used.
We assessed fish establishment patterns in the ponds in two ways. First, to characterize overall establishment success for each species, we calculated the probability of capture from all seine passes within a pond $\left(P_{\text {cap }}\right)$. Comparison of mean $P_{\text {cap }}$ across all ponds indicated whether or not a species consistently established. Second, we assessed overall rates of establishment by plotting $P_{\text {cap }}$ for each species against pond age, fitting an exponential increase toward the maximum $P_{\text {cap }}$ (which is $1)$ :

$$
y=1-e^{-b x}
$$

where $y$ represents predicted $P_{\text {cap }}, x$ pond age, and $b$ the rate of increase toward the maximum $P_{\text {cap }}$. This rate of increase provided a fitted analogue to the global rate of establishment for the species across all ponds. This establishment rate was then used to distinguish species that established quickly vs. slowly. The effect of propagule pressure on establishment success was determined by comparing the log-transformed propagule pressures of species that did and did not establish in the ponds using a Student's $t$ test. The relationship between propagule pressure and the establishment rate was also examined.

Because the environmental and reproductive adaptations of freshwater fish can affect their ability to establish in new ecosystems (Olden and Poff 2006), we compared critical life-history characteristics of all species found within the irrigation ponds. These included age at maturity, reproductive and environmental guilds (after Balon 1975) and feeding guilds, which were derived using diet preferences summarized by Skelton (2001). We also compared the native temperature ranges of each species to those recorded in the ponds, as temperature tolerance may also affect establishment success (Kolar and Lodge 2002).

To assess other potential environmental drivers of population establishment within the ponds, we estimated densities of establishing species using mean catch per unit effort (number of fish per square meter sampled by each seine pull). These relative density estimates were regressed against habitat variables, propagule pressure and network distance to source in a general linear model (GLM). Initial runs of the GLM were used to remove colinear habitat variables that produced variance inflation $>2$ within the partial correlations, and a final set of orthogonal independent variables was tested for a significant effect on fish density. These variables were dam-specific propagule pressure (estimated total immigrating fish), pond depth $(\mathrm{m})$, conductivity $(\mathrm{mS} / \mathrm{m})$, percentage cover of marginal vegetation, and distance between the pond and the invasion source along the irrigation network (m). The season in which sampling occurred (summer or winter) was added as a categorical variable. Incidentally occurring species (recorded in few ponds) were not included in this analysis. Continuous variables were log transformed and percentage data arcsine-square-root transformed to meet GLM assump- 
tions of normality and homoscedasticity. The GLM analyses were performed using Statistica 10 (Statsoft 2011).

\section{Results}

\section{Fish species distributions and community shifts relative to dispersal barriers}

Twenty-one fish species were recorded from surveys in Darlington reservoir, the irrigation network, and four distinct zones in the Sundays River main stream that were separated by known barriers to upstream fish movement (Fig. 1, Table 1). The furthest downstream zone, representing sites in the estuarine influenced reaches below the Biggs causeway, contained five species unique to the zone. These species were all marinespawning species that seldom enter purely freshwater environments. Six species occurred in the Sundays River parallel to the irrigation network, but not in the network itself nor in the river upstream of Korhaansdrift weir, the off-take point for the network (Fig. 1). Comparisons of fish communities in various reaches of the Sundays River using Jaccard's coefficient revealed two major discontinuities in community similarity. Fish communities within the Darlington reservoir, the upper Sundays River, the Korhaansdrift off-take and the irrigation ponds were significantly similar to each other but not to the other sampled communities, whereas the estuarineinfluenced fish community was significantly different from this group of similar fish communities (see Appendix B for statistical outputs).

\section{Assessment of propagule pressure into the irrigation network}

Measures of propagule pressure at the network inflow revealed that the native Glossogobius callidus and the alien Gambusia affinis were the most abundant species entering the irrigation network, with an average of 244 of the former species and 81 of the latter species being captured for every $100000 \mathrm{~m}^{3}$ filtered (Table 2; see Appendix C for raw catch data). The native Gilchristella aestuaria (23 fish $/ 10^{6} \mathrm{~m}^{3}$ ) and alien Oreochromis mossambicus (19 fish $/ 10^{6} \mathrm{~m}^{3}$ ) were moderately abundant. The native Labeo umbratus and alien Cyprinus carpio were relatively scarce $\left(<10 \mathrm{fish} / 10^{6} \mathrm{~m}^{3}\right)$, whereas the alien Clarias gariepinus and Labeobarbus aeneus and the native Anguilla mossambica were extremely scarce $\left(<1 \mathrm{fish} / 10^{6} \mathrm{~m}^{3}\right)$. One species present in the river upstream and in a single sampled pond, the alien Labeo capensis, was never captured at the off-take and was not included in subsequent analyses. In total, nine species were assessed.

\section{Patterns of species establishment in ponds}

When mean $P_{\text {cap }}$ of fish species across all ponds was compared, four species grouped together with a relatively high mean $P_{\text {cap }}$, four species grouped together with a relatively low mean $P_{\text {cap }}$, and one $(C$. carpio) grouped with neither, having a mean $P_{\text {cap }}$ of 0.43 (Fig. 2a). All species with high mean $P_{\text {cap }}$ had a $P_{\text {cap }}$ of 1 in the majority ponds older than 10 years (Fig. 3a-d), indicating that population establishment generally occurred in the first decade after pond filling. Cyprinus carpio establishment appeared inconsistent over time (Fig. 3e). The remaining species all had low mean $P_{\text {cap }}$ that corresponded to random, low density incidence across the range of ponds (e.g., A. mossambica; Fig. 3f).

In the four species where population establishment generally occurred, the exponential rate of establishment ( $b$ in Eq. 1) varied from $1.11 \mathrm{yr}^{-1}$ in $G$. callidus to 0.41 $\mathrm{yr}^{-1}$ in G. aestuaria (Table 2, Fig. 3). Glossogobius callidus established fastest, with $P_{\text {cap }}=1$ being attained in all but one pond older than three years (Fig. 3a). Cyprinus carpio in contrast established slowly at a rate of $0.07 \mathrm{yr}^{-1}$ and was absent in many ponds older than 10 years (Fig. 3e). Propagule pressure was significantly higher for the four establishing species together with $C$. carpio when compared to that of the remaining nonestablishing species captured at the off-take $(t=4.04$, df $=7, P<0.005)$. When the rate of population establishment based on pond survey $P_{\text {cap }}$ was plotted against propagule pressure for all species (Fig. 2b), the interspecific relationship closely fitted a saturation response curve $\left(F_{2,7}=836.74 ; P<0.0001\right.$; adjusted $R^{2}$ $=0.99)$.

\section{Influence of biological and environmental variables on establishment patterns}

The measured temperature range in the study ponds $\left(10-31^{\circ} \mathrm{C}\right)$ fell within the thermal tolerance of $O$. mossambicus $\left(7-37^{\circ} \mathrm{C}\right)$, G. affinis $\left(4-38^{\circ} \mathrm{C}\right)$, C. carpio $\left(4-36^{\circ} \mathrm{C}\right)$, and $C$. gariepinus $\left(8-35^{\circ} \mathrm{C}\right.$; De Moor and Bruton 1988). These temperatures were also similar to the temperature range experienced by the native $G$. callidus and $G$. aestuaria in South African estuaries (Strydom and Neira 2006) and by L. aeneus, L. capensis, and L. umbratus in Lake Gariep (Winker et al. 2011). The establishing species represented a variety of reproductive, environmental and feeding guilds (Table 3). Cyprinus carpio was the only benthic spawning species apparently capable of establishing in the ponds, while fish with reproductive strategies not requiring substrate generally always established (Fig. 4).

General linear models (see full effects in Appendix D) were used to assess the effects of dam-specific propagule pressure, depth, conductivity, percentage of marginal vegetation, distance from immigration source, and sampling season, on the relative density of the four establishing species, as well as $C$. carpio and $C$. gariepinus, which had been expected a priori to establish in the majority of ponds due to their invasive biology in South Africa (Cambray 2003, Winker et al. 2011). Densities of G. callidus, G. aestuaria, O. mossambicus, and $C$. gariepinus were positively correlated with propagule pressure (Table 4). Gambusia affinis and $O$. mossambicus densities were positively associated with ponds sampled in summer, while $C$. carpio was 
TABLE 1. Distribution of species in the Sundays River system from Darlington reservoir.

\begin{tabular}{|c|c|c|c|c|c|c|c|c|}
\hline Species & Group & DR & UR & $\mathrm{IO}$ & IP & $\mathrm{CW}$ & LR & EI \\
\hline Cyprinus carpio & A & 1 & 1 & 1 & 1 & 1 & 1 & 1 \\
\hline Gambusia affinis & A & 1 & 1 & 1 & 1 & 1 & 1 & 1 \\
\hline Oreochromis mossambicus & A & 1 & 1 & 1 & 1 & 1 & 1 & 1 \\
\hline Tilapia sparrmanii & A & 0 & 0 & 0 & 0 & 1 & 1 & 1 \\
\hline Clarias gariepinus & $\mathrm{O}$ & 1 & 1 & 1 & 1 & 1 & 1 & 1 \\
\hline Labeo capensis & $\mathrm{O}$ & 1 & 1 & 0 & 1 & 0 & 0 & 0 \\
\hline Labeobarbus aeneus & $\mathrm{O}$ & 1 & 1 & 1 & 1 & 0 & 0 & 0 \\
\hline Barbus pallidus & $\mathrm{N}$ & 0 & 0 & 0 & 0 & 1 & 1 & 1 \\
\hline Gilchristella aestuaria & $\mathrm{N}$ & 1 & 1 & 1 & 1 & 1 & 0 & 0 \\
\hline Glossogobius callidus & $\mathrm{N}$ & 1 & 1 & 1 & 1 & 1 & 1 & 1 \\
\hline Labeo umbratus & $\mathrm{N}$ & 1 & 1 & 1 & 1 & 0 & 1 & 0 \\
\hline Anguilla marmorata & $\mathrm{E}$ & 0 & 0 & 0 & 0 & 0 & 1 & 1 \\
\hline Anguilla mossambica & $\mathrm{E}$ & 1 & 1 & 1 & 1 & 1 & 1 & 1 \\
\hline Argyrosomus japonicas & $\mathrm{M}$ & 0 & 0 & 0 & 0 & 0 & 0 & 1 \\
\hline Lithognathus lithognathus & $\mathrm{M}$ & 0 & 0 & 0 & 0 & 0 & 0 & 1 \\
\hline Liza trimaculatus & $\mathrm{M}$ & 0 & 0 & 0 & 0 & 0 & 0 & 1 \\
\hline Monodactylus falciformis & M & 0 & 0 & 0 & 0 & 0 & 1 & 1 \\
\hline Mugil cephalus $\dagger$ & M & 1 & 0 & 0 & 0 & 0 & 1 & 1 \\
\hline Myxus capensis & M & 0 & 0 & 0 & 0 & 0 & 1 & 1 \\
\hline Pomadasys commersonii & M & 0 & 0 & 0 & 0 & 0 & 0 & 1 \\
\hline Rhabdosargus holubi & $\mathrm{M}$ & 0 & 0 & 0 & 0 & 0 & 0 & 1 \\
\hline
\end{tabular}

Notes: Species are categorized as alien to the system (A); alien Orange River fauna (O); native freshwater spawning fish (N); catadromous eel (E); and marine spawning fishes (M). Faunal zones along the Sundays River are divided as follows: within Darlington reservoir (DR); river upstream of the off-take canal at Korhaansdrift (UR); inside the off-take canal (IO); inside the irrigation ponds (IP); river upstream of Cleveland weir in the middle reaches $(\mathrm{CW})$; lower river between Cleveland weir and the Biggs causeway (LR); and below Biggs causeway in the estuarine-influenced zone (EI). A number 1 indicates species presence; a 0 indicates absence.

$\dagger$ The presence of Mugil cephalus in the Darlington reservoir is a result of stocking and not unaided penetration of upstream barriers.

negatively associated with a high percentage of marginal vegetation (Table 4).

\section{Discussion}

The importance of propagule pressure for the establishment success of introduced fish has long been acknowledged, though quantitative assessment of its significance has been lacking (García-Berthou 2007). We demonstrated that a natural experiment, involving multiple water bodies of differing ages and a single introduction source, could be used to derive quantitative estimates of continuous propagule pressure. Propagule pressure measured in this way drove establishment rates for several fish species over 30 years of introductions.

\section{Community structure and dispersal topology in the irrigation network}

Shifts in community structure across the Sundays River catchment reflected barriers to migration and the unidirectional source-sink structure of the irrigation system. All species present at the IBWT inflow were found downstream in the ponds. The communities within the reservoir, ponds and all sampled areas between Darlington reservoir and Korhaansdrift weir

TABLE 2. Exponential and linear regressions fitted to $P_{\text {cap }}$ of each species against pond age, to determine overall rates of establishment across the irrigation network.

\begin{tabular}{|c|c|c|c|c|c|c|}
\hline Species & $\begin{array}{c}\text { Estimated propagule } \\
\text { pressure }\end{array}$ & Regression type & $\begin{array}{l}\text { Establishment rate } \\
\text { estimate, } b\end{array}$ & SE & $F_{1,29}$ & $P$ \\
\hline GLC & 244.14 & exponential & 1.11 & 0.20 & 1187.73 & $<0.001$ \\
\hline GAA & 81.49 & exponential & 0.84 & 0.26 & 258.76 & $<0.001$ \\
\hline ORM & 19.45 & exponential & 0.42 & 0.09 & 268.74 & $<0.001$ \\
\hline GIA & 23.02 & exponential & 0.41 & 0.09 & 264.06 & $<0.001$ \\
\hline CYC & 4.33 & exponential & 0.08 & 0.03 & 23.67 & $<0.001$ \\
\hline CLG & 0.13 & linear & 0.01 & 0.006 & 5.91 & 0.02 \\
\hline LAU & 2.22 & linear & 0.002 & 0.003 & 0.32 & 0.58 \\
\hline ANM & 0.91 & linear & 0.002 & 0.002 & 2.46 & 0.13 \\
\hline LAA & 0.03 & linear & 0.0001 & 0.001 & 0.03 & 0.87 \\
\hline
\end{tabular}

Notes: We fitted an exponential increase toward $P_{\text {cap }}=1$ over time to establishing species and a linear increase in $P_{\text {cap }} \approx 0$ over time to non-establishing species. Species modeled included Glossogobius callidus (GLC), Gambusia affinis (GAA), Gilchristella aestuaria (GIA), Cyprinus carpio (CYC), Oreochromis mossambicus (ORM), Clarias gariepinus (CLG), Labeo umbratus (LAU), Labeobarbus aeneus (LAA), and Anguilla mossambica (ANM). Estimated propagule pressure (fish per $1000000 \mathrm{~m}^{3}$ ) represents mean density of fish entering the irrigation network across all seasons, weighted by seasonal variation in pond inflow. An exponential regression means an exponential increase toward $1\left(y=1-e^{-b x}\right)$; a linear regression means a linear increase $(y=b x)$. 

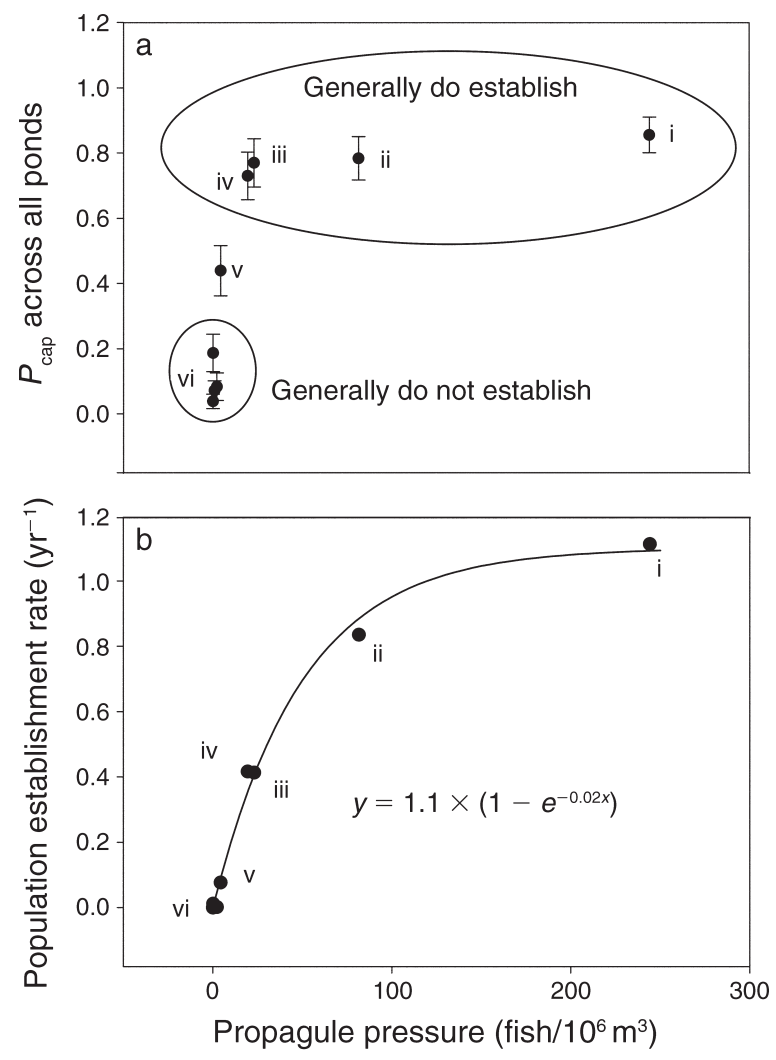

FIG. 2. Relationships between propagule pressure at the network immigration source and (a) probability of capture $\left(P_{\text {cap }}\right.$; mean $\left.\pm \mathrm{SE}\right)$ for each species across all surveyed ponds and (b) rates of population establishment for each species. Differences in mean $P_{\text {cap }}$ illustrate two colonization types in the fish fauna: those that regularly established populations in most ponds and those that did not establish but were recorded incidentally. Four species, Glossogobius callidus (i), Gambusia affinis (ii), Gilchristella aestuaria (iii), and Oreochromis mossambicus (iv), generally established. One species, Cyprinus carpio (v), had an intermediate $P_{\text {cap }}$, grouping neither with the establishing species nor the non-establishing species. The catadromous eel Anguilla mossambica (vi) and three other species (Clarias gariepinus, Labeo umbratus, and Labeobarbus aeneus) did not establish in any ponds. Establishment rate displays a saturation response curve to propagule pressure, with the two fastest-establishing species receiving many more propagules than they could use to establish more rapidly in the ponds.

were significantly similar to each other, indicating a continuous dispersal pathway from the IBWT into the ponds. In contrast, six species found in the Sundays River parallel to the majority of the canal network were never recorded in the ponds. Their absence resulted in no significant similarity between the pond and lower Sundays River fish communities, and suggests that there was no way for these species to enter the network downstream of the Korhansdrift off-take. These findings make us confident that there is only one entry point to the network, and consequently that propagule pressure recorded at the off-take can be regarded as the propagule pressure for all surveyed ponds.

\section{Establishment patterns in irrigation ponds}

Of the nine fish species entering the irrigation network, five species formed established populations within ponds, with varying establishment rates. An interaction between propagule pressure and reproductive adaptation could explain the majority of species' establishment success. The fastest colonizer was the native G. callidus, which was found in all surveyed ponds older than six months. This pelagic-spawning eurytopic species is successful in estuarine and freshwater environments across the eastern catchments of South Africa (Whitfield 1998, Lukey et al. 2006, Strydom and Neira 2006), suggesting a potential for colonizing novel habitats like artificial impoundments. Propagule pressure from the canal network significantly correlated with G. callidus densities within the ponds, and appears a major driver of colonization success in this species.

The second fastest colonizer, the alien G. affinis is well known for its ability to establish in lentic freshwater environments in South Africa (van Rensburg et al. 2011). General linear modeling revealed significantly higher densities present in ponds sampled in summer, which reflects the seasonal "boom-bust" population dynamics to which this species is prone (Pyke 2005). These severe seasonal fluctuations in population density may have masked their relationship to propagule pressure, though the species appeared to colonize the ponds faster than G. aestuaria, which received far fewer propagules overall than G. affinis. Gilchristella aestuaria, a pelagic spawner (Wooldridge and Bailey 1982), is not constrained by habitat for reproduction, and is capable of reaching sexual maturity within the ponds over the course of a summer breeding season (D. Woodford, unpublished data). Given its life-history strategy, and since propagule pressure was the only significant predictor of $G$. aestuaria biomass, the relatively low propagule pressure detected for this species was likely the main factor hampering its ability to colonize the ponds as rapidly as G. callidus and G. affinis.

Oreochromis mossambicus also established in the majority of ponds, and its density was positively associated with both propagule pressure and summer sampling. This finding indicates both a positive effect of propagules on population size, as well as high winter mortality of juvenile fish, which has been recorded in a South African estuary at similar latitude to the Sundays River (Ellender et al. 2008). Densities of Cyprinus carpio, the only other species to establish, did not show significant associations with propagule pressure but were instead negatively associated with percentage marginal vegetation. The apparent randomness of $C$. carpio distributions and densities across the surveyed ponds makes this association difficult to interpret. Rather, the fact that this species is a benthic spawner, requiring shallow submerged vegetation on which to lay eggs (Crivelli 1981) may explain this random failure to establish. Filling and drawing down of the ponds happens weekly, if not daily, and is severe enough in 


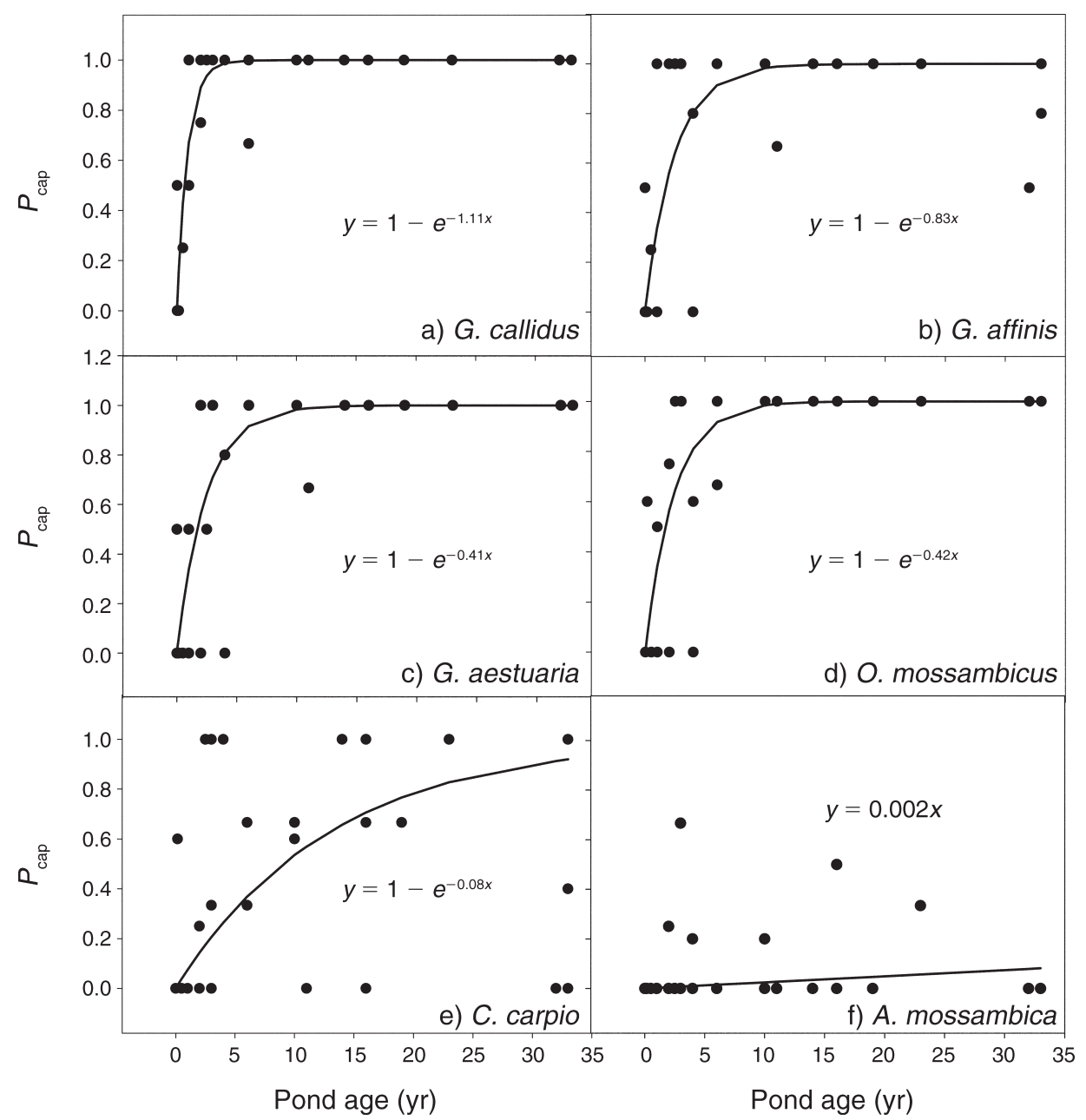

FIG. 3. Patterns of establishment within the ponds modeled by fitting an exponential function (Eq. 1), where the $x$-axis is pond age and the $y$-axis is $P_{\text {cap }}$ within a pond. Establishing species include (a) Glossogobius callidus and (b) Gambusia affinis, which always established and established quickly; (c) Gilchristella aestuaria and (d) Oreochromis mossambicus, which always established, but slowly; and (e) Cyprinus carpio, which appeared to establish only in some ponds. (f) The catadromous eel Angulilla mossambica provides an example of a fish species that did not establish in any ponds.

TABLE 3. Life history characteristics of 10 fish species recorded in ponds within the Sundays irrigation network.

\begin{tabular}{|c|c|c|c|c|c|}
\hline Species & $\begin{array}{c}\text { Age at } \\
\text { maturity }\end{array}$ & $\begin{array}{l}\text { Reproductive } \\
\text { guild }\end{array}$ & $\begin{array}{c}\text { Environmental } \\
\text { guild }\end{array}$ & $\begin{array}{l}\text { Trophic } \\
\text { guild }\end{array}$ & Main reference \\
\hline Glossogobius callidus & $<1 \dagger$ & PS & BWE & $\mathrm{ZPL} / \mathrm{INV}$ & Strydom and Neira (2006) \\
\hline Gambusia affinis & $<1$ & LB & PLE & ZPL/INV & Pyke (2005) \\
\hline Gilchristella aestuaria & $<1$ & PS & BWE & ZPL & D. Woodford, unpublished data \\
\hline Oreochromis mossambicus & $1-2$ & MB & ETR & AIL & Weyl and Hecht (1998) \\
\hline Cyprinus carpio & $2-3$ & BSP & ETR & INV & Winker et al. (2011) \\
\hline Clarias gariepinus & $1-2$ & BSP & ETR & ZPL/INV/PIS & Bruton (1979) \\
\hline Labeo umbratus & $3-5$ & BSP & ETR & INV & Potts et al. (2006) \\
\hline Labeobarbus aeneus & $3-7$ & BSG & ETR & INV & Weyl et al. (2009) \\
\hline Anguilla mossambica & $>10$ & PS & ETR & INV/PIS & Lin et al. (2012) \\
\hline
\end{tabular}

Notes: Reproductive and environmental guilds follow those of Balon (1975): PS, non-guarding pelagic spawner; BSP, nonguarding benthic spawner on plants; BSG, non-guarding benthic spawner on gravel; MB, mouth brooder; LB, live bearer. Environmental guilds follow definitions of Welcomme et al. (2006): BWE, brackish water estuarine; PLE, plesiopotamonic; ETR, eupotamonic riparian; CAT, catadromous. Trophic guild was categorized according to diet as summarized in Skelton (2001): ZPL, zooplanktivore; INV, invertivore; AIL, algivores/iliophage; PIS, piscivore.

$\dagger G$. callidus age at maturity is not known but is assumed to be under a year. 


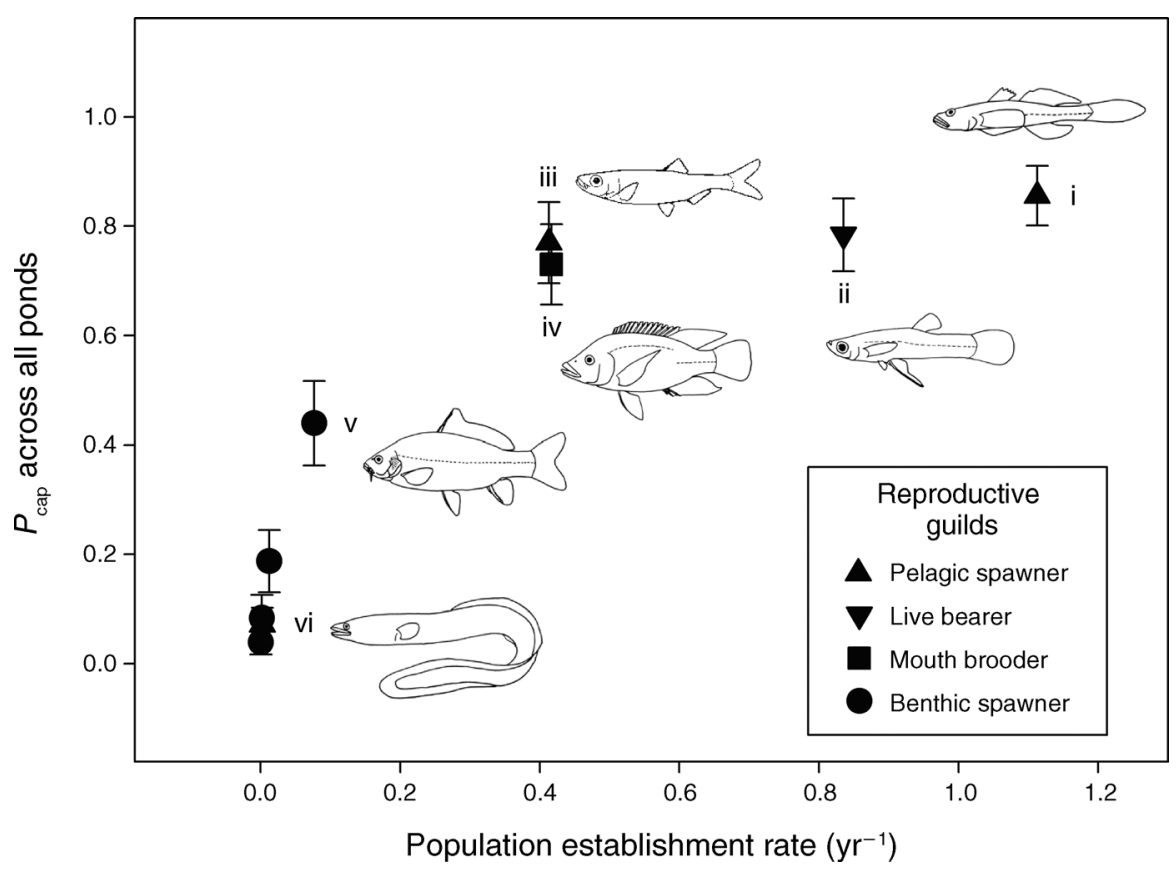

FIG. 4. The relationship between establishment rate and $P_{\text {cap }}($ mean $\pm \mathrm{SE})$ illustrates the range of colonization ability displayed by the nine species captured within the ponds, indicating the reproductive guild of each species (see Table 3). Rapidly establishing species included Glossogobius callidus (i), a pelagic spawner, and Gambusia affinis (ii), a live-bearer. Slowly establishing species included pelagic spawning Gilchristella aestuaria (iii), mouth-brooding Oreochromis mossambicus (iv), and benthic spawning Cyprinus carpio (v). The remaining fishes that did not establish (Clarias gariepinus, Labeo umbratus, and Labeobarbus aeneus) are all benthic spawners with the exception of the catadromous pelagic spawner Anguilla mossambica (vi).

some cases that large proportions of the pond bed may become regularly exposed. This process could hamper successful incubation in C. carpio eggs and drive failure to establish. That all four other establishing species belong to reproductive guilds not dependent on substrate supports this hypothesis.

Among the non-establishing species, Clarias gariepinus was a surprising failure, as it is known to be a good colonizer of lentic water bodies (Cambray 2003). Despite its low incidence in the ponds, densities of this species were positively associated with propagule pressure. Being a benthic spawner (Bruton 1979), it is also vulnerable to pond level fluctuations, to the extent that the majority of $C$. gariepinus captured may have been propagules rather than local recruits. A clear example of presence with no recruitment is the catadromous eel Anguilla mossambica, which is a marine spawning species (Lin et al. 2012). The distribution of $A$. mossambica across the ponds thus represents the surviving propagules still present after 33 years of sporadic introductions. Although by our criteria $C$. carpio was able to establish populations in seven of the 30 ponds, the possibility that these populations contained only propagules cannot be excluded.

Breeding adaptation can also explain the incidental presence of L. aeneus, which require flood-derived cues for spawning (Weyl et al. 2009) and are thus unlikely to reproduce in the ponds even with sufficient propagule pressure. In contrast, while L. umbratus is able to breed in small impoundments (Potts et al. 2006), its incidental

TABLE 4. Parameter estimates for environmental variables with significant $(P<0.05)$ effects on the density of colonizing fish species in the irrigation ponds, based on general linear modeling (see Appendix D for full effects tables).

\begin{tabular}{lcc}
\hline \hline \multicolumn{1}{c}{ Effect } & Relationship & Parameter coefficient \\
\hline Glossogobius callidus vs. propagule pressure & + & $0.08(0.03,0.14)$ \\
Gambusia affinis vs. season (summer) & + & $0.18(0.01,0.35)$ \\
Oreochromis mossambicus vs. propagule pressure & + & $0.13(0.02,0.23)$ \\
Oreochromis mossambicus vs. propagule pressure & + & $0.21(0.04,0.76)$ \\
Gilchristella aestuaria vs. propagule pressure & + & $0.22(0.01,0.43)$ \\
Cyprinus carpio vs. percent marginal vegetation & - & $0.08(0.16,0.002)$ \\
Clarias gariepinus vs. propagule pressure & + & $0.006(0.002,0.009)$
\end{tabular}

Notes: Relationships are either positive $(+)$ or negative $(-)$. Upper and lower $95 \%$ confidence limits are given in parentheses. 
distribution across the irrigation network was likely driven by its very low propagule pressure at the introduction source. It appears that temperature tolerance, environmental guild and feeding guild had no consistent effect on any of the nine species' ability to colonize the ponds.

\section{The role of propagule pressure in driving establishment success}

The patterns of establishment for the majority of species surveyed in the ponds reflect a combined effect of propagule pressure originating from the irrigation network and the reproductive strategies of the individual species. While this finding agrees with results of previous studies of fish invasions that used semiquantitative, qualitative, or historical data to characterize propagule pressure (Marchetti et al. 2004, Ruesink 2005, Duggan et al. 2006), our study used quantitative estimates of relative immigration rates to demonstrate the nature of the role of propagule pressure in determining species-specific establishment rates in downstream habitats.

Establishing species in the irrigation network received significantly more propagules than incidental species, and establishment rates displayed a saturation response curve to propagule pressure within the ponds. This response indicates not only that relative interspecific rates of establishment were driven by propagule size, but that the two fastest establishing species (G. callidus and G. affinis) received potentially thousands more colonists than necessary to maximize their establishment rate. These findings support the notion that on-going propagule pressure acts as a key driving force in overcoming the demographic and environmental resistance barriers that allow introduced fish to reach the establishment stage (Marchetti et al. 2004). Furthermore, those species with life-history strategies that prevent population establishment in the ponds ( $A$. mossambicus, L. aeneus) are powerful indicators of the effect of continuous propagule pressure on range expansion without establishment. Every single species introduced from the Sundays River into the irrigation network was recorded downstream in the ponds, regardless of how scarce they were at the immigration source. In the context of Moyle and Light's (1996) fish invasion framework, every species ever introduced into the Sundays River by the IBWT reached the arrival stage within the environments of the ponds.

This pattern highlights the difference between many active human-mediated fish introductions (e.g., introduction to a water body by anglers) and a passive IBWT-mediated fish introduction. Simberloff (2009) distinguished between propagule size (number of individuals in a one-off introduction) and propagule number (number of discreet introduction events). Propagule number over time has often had a significant effect of pushing a species through the demographic and genetic barriers that divide the establishment and invasion stages (Roman and Darling 2007, Simberloff 2009). For example, successful salmonid invasions are generally the result of repeated stockings, or continuous escapement from aquaculture, rather than large once-off introductions by individuals (Colautti 2005, Arismendi et al. 2009). The constant trickle of fish propagules into the irrigation network from the upstream IBWT appears to have ensured that no matter how small the propagule size, arrival in some ponds was eventually guaranteed.

\section{Conservation implications}

The ability of the irrigation network to provide a continuous supply of propagules to the receiving environments downstream underscores the danger posed by IBWT schemes to fish conservation. The global implications of this introduction pathway are most troubling when compared to other pathways such as angler introductions and the pet trade. Whereas these pathways tend to be good for few, highly desired, species used for ornamentation or recreation (Richardson et al. 2003, Duggan et al. 2006), IBWTs represent a pathway that is indiscriminate, providing continuous propagule pressure for any species moving from the donor catchment to the receiving catchment. In this way, undesirable species can arrive in receiving catchments, and without any further human intervention will establish and eventually invade if they possess appropriate life-history strategies. IBWTs effectively break down the biogeographic barriers between entire fish communities, making them a powerful driver of landscape-scale fish community homogenization (Rahel 2007).

As human populations grow and water demand for urban and agricultural use increases, IBWTs are increasingly being used to increase water supply (Meador 1992, Fairless 2008). One known consequence has been the transfer of five native and two alien fishes from northern to southern California via aqueducts (Moyle and Marchetti 2006). In India, a proposed multiple-basin transfer scheme has the potential to homogenize fish communities at a subcontinental scale, with unclear consequences for ecological integrity (Campbell-Grant et al. 2012). The ease with which fish species can be introduced to new ecosystems through water transfer infrastructure emphasizes the need for preventative measures to be considered in the planning stages of such projects. While physical barriers such as fish screens and electrical barriers have been used to limit fish dispersal, these methods are rarely, if ever, completely effective (Rahel 2007) and their implementation may involve economic trade-offs for the beneficiaries of the scheme (Koehn and Mackenzie 2004). It is thus critical that the social, environmental and ultimately economic impacts of fish introductions be weighed against the benefits of IBWTs when determining the cost and viability of these engineering projects. 


\section{ACKNOWLEDGMENTS}

This study was jointly funded by a Water Research Commission research grant (WRC Project \#K5/2039) and a National Research Foundation post-doctoral fellowship (to D. J. Woodford). C. Hui, D. M. Richardson, and O. L. F. Weyl acknowledge support from the DST-NRF Centre of Excellence for Invasion Biology. C. Hui and D. M. Richardson received additional support from the National Research Foundation (grant 85417 to D. M. Richardson). We thank R. Wasserman, V. Kunz, T. Bellingan, J. Kinghorn, N. Mazungula, K. van der Walt, and D. Howell for assistance in the field. We thank H. Du Plessis and the water management staff of the Lower Sundays River Water Users Association for their support and advice in the planning of the project, and for providing GIS databases on the irrigation scheme. We thank the many landowners of the Sundays River valley for land access, and SAIAB staff E. Wolhuter and F. Lamont for logistical support. Fieldwork was performed in accordance with SAIAB Animal Ethics guidelines. Permits to sample freshwater fishes in the Sundays River system were issued by the Eastern Cape Department of Economic Development and Environmental Affairs (DEDEA) and South African National Parks. We thank two anonymous reviewers, whose comments greatly improved our manuscript.

\section{Literature Cited}

Arismendi, I., D. Soto, B. Penaluna, C. Jara, C. Leal, and J. León-Muñoz. 2009. Aquaculture, non-native salmonid invasions and associated declines of native fishes in Northern Patagonian lakes. Freshwater Biology 54:1135-1147.

Balon, E. K. 1975. Reproductive guilds in fishes: a proposal and definition. Journal of the Fisheries Research Board of Canada 32:821-864.

Blackburn, T. M., P. Pyšek, S. Bacher, J. T. Carlton, R. P. Duncan, V. Jarošík, J. R. U. Wilson, and D. M. Richardson. 2011. A proposed unified framework for biological invasions. Trends in Ecology and Evolution 26:333-339.

Bruton, M. N. 1979. The breeding biology and early development of Clarias gariepinus (Pisces: Clariidae) in Lake Sibaya, South Africa, with a review of breeding in species of the subgenus Clarias (Clarias). Transactions of the Zoological Society of London 35:1-45.

Cambray, J. 2003. The need for research and monitoring on the impacts of translocated sharptooth catfish, Clarias gariepinus, in South Africa. African Journal of Aquatic Science 28:191-195.

Campbell-Grant, E. H., H. J. Lynch, R. Muneepeerakul, M. Arunachalam, I. Rodríguez-Iturbe, and W. F. Fagan. 2012. Interbasin water transfer, riverine connectivity, and spatial controls on fish biodiversity. PLoS ONE 7:e34170.

Colautti, R. I. 2005. Are characteristics of introduced salmonid fishes biased by propagule pressure? Canadian Journal of Fisheries and Aquatic Science 62:950-959.

Colautti, R. I., I. Grigorovich, and H. J. MacIsaac. 2006. Propagule pressure: a null model for biological invasions. Biological Invasions 8:1023-1037.

Copp, G. H., M. Templeton, and R. E. Gozlan. 2007. Propagule pressure and the invasion risks of non-native freshwater fishes: a case study in England. Journal of Fish Biology 71:148-159.

Cox, J. G., and S. L. Lima. 2006. Naiveté and an aquaticterrestrial dichotomy in the effects of introduced predators. Trends in Ecology and Evolution 21:674-680.

Crivelli, A. J. 1981. The biology of the common carp, Cyprinus carpio L. in the Camargue, southern France. Journal of Fish Biology 18:271-290.

De Moor, I. J., and M. N. Bruton. 1988. Atlas of alien and translocated indigenous aquatic animals in southern Africa. South African National Scientific Programmes Report 144. Foundation for Research Development and Council for Scientific and Industrial Research, Pretoria, South Africa.
Duggan, I. C., C. A. M. Rixon, and H. J. MacIsaac. 2006. Popularity and propagule pressure: determinants of introduction and establishment of aquarium fish. Biological Invasions 8:377-382.

Ellender, B. R., O. L. F. Weyl, M. K. Shanyengange, and P. D. Cowly. 2008. Juvenile population dynamics of Oreochromis mossambicus in an intermittently open estuary at the limit of its natural distribution. African Zoology 43:277-283.

ESRI. 2011. ArcGIS 10. ESRI, Redlands, California, USA.

Fairless, D. 2008. Water: muddy waters. Nature 452:278-281.

Fausch, K., Y. Taniguchi, S. Nakano, G. Grossman, and C. R. Townsend. 2001. Flood disturbance regimes influence rainbow trout invasion success among five holarctic regions. Ecological Applications 11:1438-1455.

García-Berthou, E. 2007. The characteristics of invasive fishes: what has been learned so far? Journal of Fish Biology 71:33-55.

Hayes, K. R., and S. C. Barry. 2008. Are there any consistent predictors of invasion success? Biological Invasions 10:483506.

Holway, D. A. 1998. Factors governing rate of invasion: a natural experiment using Argentine ants. Oecologia 115:206212.

Humphrey, L. D., and E. W. Schupp. 2004. Competition as a barrier to establishment of a native perennial grass (Elymus elymoides) in alien annual grass (Bromus tectorum) communities. Journal of Arid Environments 58:405-422.

Koehn, J. D., and R. F. Mackenzie. 2004. Priority management actions for alien freshwater fish species in Australia. New Zealand Journal of Marine and Freshwater Research 38:457472.

Kolar, C. S., and D. M. Lodge. 2002. Ecological predictions and risk assessment for alien fishes in North America. Science 298:1233-1236.

Lin, Y.-J., B. M. Jessop, O. L. F. Weyl, Y. Iizuka, S.-H. Lin, W. N. Tzeng, and C. L. Sun. 2012. Regional variation in otolith $\mathrm{Sr}: \mathrm{Ca}$ ratios of African longfinned eel Anguilla mossambica and mottled eel Anguilla marmorata: a challenge to the classic tool for reconstructing migratory histories of fishes. Journal of Fish Biology 81:427-441.

Lockwood, J., P. Cassey, and T. Blackburn. 2009. The more you introduce the more you get: the role of colonization pressure and propagule pressure in invasion ecology. Diversity and Distributions 15:904-910.

Lukey, J. R., A. J. Booth, and P. W. Froneman. 2006. Fish population size and movement patterns in a small intermittently open South African estuary. Estuarine, Coastal and Shelf Science 67:10-20.

Marchetti, M. P., P. B. Moyle, and R. Levine. 2004. Alien fishes in California watersheds: characteristics of successful and failed invaders. Ecological Applications 14:587-596.

Meador, M. R. 1992. Inter-basin water transfer: ecological concerns. Fisheries 17:17-22.

Memmott, J., P. G. Craze, H. M. Harman, P. Syrett, and S. V. Fowler. 2005. The effect of propagule size on the invasion of an alien insect. Journal of Animal Ecology 74:50-62.

Moyle, P. B., and T. Light. 1996. Biological invasions of fresh water: empirical rules and assembly theory. Biological Conservation 78:149-161.

Moyle, P. B., and M. P. Marchetti. 2006. Predicting invasion success: freshwater fishes in California as a model. BioScience 56:515-524.

Olden, J., and N. Poff. 2006. Life-history strategies predict fish invasions and extirpations in the Colorado River Basin. Ecological Monographs 76:25-40.

Potts, W., A. Booth, T. Hecht, and T. Andrew. 2006. The life history and fishery potential of Labeo umbratus (Teleostei: Cyprinidae) in five small South African reservoirs. African Journal of Aquatic Science 31:37-41.

Pyke, G. H. 2005. A Review of the biology of Gambusia affinis and G. holbrooki. Reviews in Fish Biology and Fisheries 15:339-365. 
Rahel, F. J. 2007. Biogeographic barriers, connectivity and homogenization of freshwater faunas: it's a small world after all. Freshwater Biology 52:696-710.

Richardson, D. M., J. A. Cambray, R. A. Chapman, W. R. J. Dean, C. L. Griffiths, D. C. Le Maitre, D. J. Newton, and T. J. Winstanley. 2003. Vectors and pathways of biological invasions in South Africa-past, present and future. Pages 292-349 in G. M. Ruiz and J. T. Carlton, editors. Invasive species: vectors and management strategies. Island Press, Washington, D.C., USA.

Richardson, D. M., J. R. U. Wilson, O. L. F. Weyl, and C. L. Griffiths. 2011. South Africa: invasions. Pages 643-651 in D. Simberloff and M. Rejmánek, editors. Encyclopedia of biological invasions. University of California Press, Berkeley, California, USA.

Roman, J., and J. Darling. 2007. Paradox lost: genetic diversity and the success of aquatic invasions. Trends in Ecology and Evolution 22:454-464.

Ruesink, J. 2005. Global analysis of factors affecting the outcome of freshwater fish introductions. Conservation Biology 19:1883-1894.

Simberloff, D. 2009. The role of propagule pressure in biological invasions. Annual Review of Ecology, Evolution, and Systematics 40:81-102.

Skelton, P. 2001. A complete guide to the freshwater fishes of southern Africa. Struik Publishers, Cape Town, South Africa.

Statsoft. 2011. STATISTICA data analysis software system, version 10.0. Statsoft, Tulsa, Oklahoma, USA.

Strydom, N. A., and F. J. Neira. 2006. Description and ecology of larvae of Glossogobius callidus and Rediogobius dewaali (Gobiidae) from temperate South African estuaries. African Zoology 41:240-251.

van Rensburg, B. J., O. L. F. Weyl, S. J. Davies, L. J. van Wilgen, D. S. Peacock, D. Spear, and C. T. Chimimba. 2011. Invasive vertebrates of South Africa. Pages $326-378$ in D.
Pimentel, editor. Biological invasions: economic and environmental costs of alien plant, animal, and microbe species. Second edition. RC Press, Boca Raton, Florida, USA.

Von Holle, B., and D. Simberloff. 2005. Ecological resistance to biological invasion overwhelmed by propagule pressure. Ecology 86:3212-3218.

Welcomme, R. L., K. O. Winemiller, and I. G. Cowx. 2006. Fish environmental guilds as a tool for assessment of ecological condition of rivers. River Research and Applications 22:377-396.

Weyl, O. L. F., and T. Hecht. 1998. The biology of Tilapia rendalli and Oreochromis mossambicus (Pisces: Cichlidae) in a subtropical lake in Mozambique. South African Journal of Zoology 33:178-188.

Weyl, O. L. F., T. Stadtlander, and A. J. Booth. 2009. Establishment of translocated populations of smallmouth yellowfish, Labeobarbus aeneus (Pisces: Cyprinidae), in lentic and lotic habitats in the Great Fish River system, South Africa. African Zoology 1976:93-105.

Whitfield, A. K. 1998. Biology and ecology of fishes in southern African estuaries. Ichthyofaunal Monographs 2. J. L. B. Smith Institute of Ichthyology, Grahamstown, South Africa.

Williamson, M. H., and A. Fitter. 1996. The characters of successful invaders. Biological Conservation 78:163-170.

Wilson, J. R. U., E. E. Dormontt, P. J. Prentis, A. J. Lowe, and D. M. Richardson. 2009. Something in the way you move: dispersal pathways affect invasion success. Trends in Ecology and Evolution 24:136-144.

Winker, H., O. L. F. Weyl, A. J. Booth, and B. R. Ellender. 2011. Life history and population dynamics of invasive common carp, Cyprinus carpio, within a large turbid African impoundment. Marine and Freshwater Research 62:12701280.

Wooldridge, T., and C. Bailey. 1982. Euryhaline zooplankton of the Sundays Estuary and notes on trophic relations. South African Journal of Zoology 17:151-163.

\section{Supplemental Material}

Appendix A

Photograph of a Sundays Valley farm pond (Ecological Archives A023-093-A1).

\section{Appendix B}

Methods and results of Sundays River fish surveys (Ecological Archives A023-093-A2).

Appendix C

Raw catch data from the Sundays irrigation network (Ecological Archives A023-093-A3).

Appendix D

Full effects for general linear models (Ecological Archives A023-093-A4). 